\title{
Some new IIB group complexes of an imidazolidine ligand: Synthesis, spectral characterization, electrochemical, thermal and antimicrobial properties
}

\author{
MORTEZA MONTAZEROZOHORI ${ }^{\mathrm{a}, *}$, SAYED ALIREZA MUSAVI $^{\mathrm{a}}$, ASGHAR NAGHIHA $^{\mathrm{b}}$ \\ and SOMAYEH VEYSEH ${ }^{\mathrm{c}}$ \\ a Department of Chemistry, Yasouj University, Yasouj 75918-74831, Iran \\ ${ }^{b}$ Department of Animal Sciences, Faculty of Agriculture, Yasouj University, Yasouj 75918-74831, Iran \\ ${ }^{c}$ Applied Geological Research Center of Iran, No 7, Sarbazane Gomnam Blvd, Samad Naghdi 31746-74841, \\ Iran \\ e-mail: mmzohori@mail.yu.ac.ir; mmzohory@yahoo.com
}

MS received 24 June 2013; revised 28 October 2013; accepted 5 November 2013

\begin{abstract}
An imidazolidine Schiff base ligand, (E)-N-(4-nitrobenzylidene)-2-(2-(4-nitrophenyl) imidazolidine-1-yl) ethaneamine (L) has been synthesized by a condensation reaction between $\mathrm{N}^{\prime}$-(2-aminoethyl)ethane-1,2-diamine and 4-nitrobenzaldehyde in 1:2 ratio and then characterized by physical and spectral data. Some new complexes with general formula of $\mathrm{MLX}_{2}$ (wherein $\mathrm{M}$ is $\mathrm{Zn}$ (II), $\mathrm{Cd}$ (II) and $\mathrm{Hg}$ (II) and X is chloride, bromide and/or iodide) have been prepared and characterized by physical and spectroscopic studies such as elemental analysis, molar conductance measurements, FT-IR, ${ }^{1} \mathrm{H}$ and ${ }^{13} \mathrm{C}$ NMR and UV-Visible electronic spectra. The spectral data indicate that the ligand is coordinated to zinc(II) as a bidentate ligand in imidazolidine form but it binds to other metal salts as bis-imine tridentate ligand. Furthermore, cyclic voltammetry technique was applied for recording the electrochemical behaviour of the ligand and its complexes. Cyclic voltamogram of the ligand showed that it is reduced at four cathodic potentials and then oxidized only in two anodic potentials in reverse direction. The electrochemical behaviour of ligand is affected by coordination. Thermal analysis of ligand and its complexes revealed that they are decomposed via 3-4 thermal steps. Moreover, some activation thermodynamic parameters such as A, $\mathrm{E}^{*}, \Delta \mathrm{H}^{*}, \Delta \mathrm{S}^{*}$ and $\Delta \mathrm{G}^{*}$ were calculated based on TG/DTA plots using Coats-Redfern relation. The Schiff base ligand and its complexes have also been tested in vitro to evaluate their antimicrobial activities.
\end{abstract}

Keywords. Schiff base; spectroscopic; cyclic voltammetry; antibacterial; antifungal; thermogravimetry.

\section{Introduction}

The wide variety of possible structures for the Schiff base ligands depending upon the parent aldehydes and amines has resulted in the fast development of the chemistry of them and their complexes. Schiff base ligands as a highlighted class of organic compounds generally contain $\mathrm{O}$ and $\mathrm{N}$ donor atoms that are used for coordination to the metal ions. ${ }^{1-6}$ In recent years, the Schiff base complexes have been found as one important group of the coordination compounds due to their valuable biochemical, analytical and antimicrobial properties..$^{7-10}$ The Schiff base complexes are also applied as catalysts for a broad range of organic conversion including epoxidation of olefins, decarboxylation of arylacetic acids, hydroxylation of alkanes, polymerization of lactides and asymmetric ring opening of

*For correspondence epoxides. ${ }^{11-15}$ Furthermore, many biological properties, such as DNA cleavage activity, ${ }^{16}$ biomimetic enzyme models, ${ }^{17-19}$ tumour growth inhibitors, antivirus, anti$\mathrm{HIV}$, antifungal and antibacterial activities ${ }^{20-24}$ have also been reported for these type of compounds. A literature survey indicates that though many reports exist on the Schiff bases, their complexes and biological applications but the synthesis and investigation of some properties such as electrochemical, thermal and biological behaviour of $\mathrm{N}_{2}$ and $\mathrm{N}_{3}$ donor Schiff bases and their IIB group element complexes are scanty.

In continuation of our previous studies on transition metal Schiff base complexes, ${ }^{25-30}$ here we report the synthesis and spectral characterization of a new series of $\mathrm{MLX}_{2}$ complexes in which $\mathrm{M}$ is $\mathrm{Zn}(\mathrm{II})$, $\mathrm{Cd}(\mathrm{II})$ and $\mathrm{Hg}(\mathrm{II}) ; \mathrm{X}$ is $\mathrm{Cl}^{-}, \mathrm{Br}^{-}, \mathrm{I}^{-}$and $\mathrm{L}$ is Schiff base ligand, (E)-N-(4-nitrobenzylidene)-2-(2-(4-nitrophenyl)imidazolidin-1-yl) ethaneamine. Furthermore, 
the electrochemical, antibacterial, antifungal and thermal behaviour of all compounds were investigated.

\section{Experimental}

\subsection{Materials and methods}

All solvents, $N^{\prime}$-(2-aminoethyl)-ethane-1,2-diamine, 4nitrobenzaldehyde, zinc, cadmium and mercury salts and other chemicals were provided from Aldrich and/or Merck chemical companies and used without any further purification. For biological tests, the solid medium of nutrient agar (Merck, Germany) was used for preparing the nutrient plates while Mueller Hinton broth (Scharlab) was applied as the liquid culture media. Sabouraub dextrose agar (Oxoid, Hampshire, England) was used as solid media for preparing the plates in antifungal studies. The Escherichia coli (ATCC 25922), Pseudomonas aereuguinosa (ATCC 9027), Staphylococcus aureus (ATCC 6538) and Bacillus subtilis (ATCC 6633) were used as Gram-negative or positive bacterial strains in antibacterial activity evaluations. The FT-IR spectra of compounds were recorded on the FT/IR-JASCO-680 model in the range of 400$4000 \mathrm{~cm}^{-1}$ using $\mathrm{KBr}$ disks. Elemental analysis (C, N and $\mathrm{H}$ ) was carried out by a CHNS-932(leco) elemental analyzer. UV-Visible spectra of compounds were recorded by a JASCO-V570 spectrometer in the range of $200-800 \mathrm{~nm}$ in DMF solution. ${ }^{1} \mathrm{H}$ and ${ }^{13} \mathrm{C}$ NMR spectra were obtained by use of a Brucker DPX FTNMR spectrometer at $400 \mathrm{MHz}$ in DMSO- $\mathrm{d}_{6}$ and/or $\mathrm{CDCl}_{3}$ solvents using TMS as internal standard. Molar conductivities of the Schiff base ligand and its metal complexes were measured in DMF solution $(1.0 \times$ $\left.10^{-3} \mathrm{M}\right)$ by means of a Metrohm 712 conductometer at room temperature. The melting points or decomposition temperature $\left({ }^{\circ} \mathrm{C}\right)$ of the ligand and its complexes were recorded by a Kruss instrument. Thermogravimetric analyses of the compounds have been studied by use of STA 1500, Rheo Metric Scientific instrument in the range of room temperature to $600^{\circ} \mathrm{C}$. Cyclic voltammetric $(\mathrm{CV})$ measurements were performed using a three-electrode configuration cell connected to Sama 500 (electroanalysis system) equipped with glassy carbon as working electrode, Pt-disk as an auxiliary electrode and a silver wire as the reference electrode. $50 \mathrm{~mL}$ of sample solutions $\left(10^{-3} \mathrm{M}\right)$ in acetonitrile as well as $(n-\mathrm{Bu})_{4} \mathrm{NPF}_{6}$ (TBAHFP) $\left(10^{-3} \mathrm{M}\right)$ as supporting electrolyte were used for the $\mathrm{CV}$ record under argon atmosphere. A potential window of -2.0 to $0.5 \mathrm{~V}$ with a scan rate of $0.1 \mathrm{VS}^{-1}$ was considered for electrochemical investigation.
2.2 Synthesis of (E)-N-(4-nitrobenzylidene)-2-(2-(4nitrophenyl)imidazolidine-1-yl) ethaneamine as an imidazolidine Schiff base ligand

A solution of 4-nitrobenzaldehyde (0.302 g, $2 \mathrm{mmol})$ in methanol $(20 \mathrm{~mL})$ was added drop-wise to methanolic solution of $N^{\prime}$-(2-aminoethyl)-ethane-1,2-diamine $(0.103 \mathrm{~g}, 1 \mathrm{mmol})(10 \mathrm{~mL})$ at room temperature and then the reaction mixture was vigorously stirred. After $3 \mathrm{~h}$, the ligand as a cream precipitate was filtered and washed twice with cooled methanol and then dried on the vacuum apparatus. Some important FT/IR, UVvisible, ${ }^{1} \mathrm{HNMR}$ and ${ }^{13} \mathrm{CNMR}$ data are listed in below:

IR(KBr, $\left.\mathrm{cm}^{-1}\right)$ : 3434(m), 3209(m), 3101(w), 3071(w), 2941(w), 2886(w), 2848(w), 1645(s), 1601(s), 1518(vs), 1346(vs), 1293(w), 1106(w), 1065(w), 1013(w), 943(w), 851(s), 830(m), 749(s), 692(s), 462(w).UV-Vis [(DMF), $\left.\lambda(\mathrm{nm}) \quad\left(\varepsilon, \mathrm{M}^{-1} \mathrm{~cm}^{-1}\right)\right]$ : 278(16991). ${ }^{1} \mathrm{H}$ NMR $\left(\mathrm{CDCl}_{3}, \mathrm{ppm}\right): 8.33(\mathrm{~s}, 1 \mathrm{H})$, $8.30(\mathrm{~d}, 2 \mathrm{H}, \mathrm{J}=8.76 \mathrm{~Hz}), 8.18(\mathrm{~d}, 2 \mathrm{H}, \mathrm{J}=8.76 \mathrm{~Hz})$, $7.88(\mathrm{~d}, 2 \mathrm{H}, \mathrm{J}=8.80 \mathrm{~Hz}), 7.69(\mathrm{~d}, 2 \mathrm{H}, \mathrm{J}=8.60 \mathrm{~Hz})$, $4.40(\mathrm{~s}, 1 \mathrm{H}), \quad 3.76-2.61\left(\mathrm{~m}, 8 \mathrm{H}_{\text {ethylenic }}\right.$ and $\left.\mathrm{H}_{\mathrm{NH}}\right) .{ }^{13} \mathrm{C}$ NMR $\left(\mathrm{CDCl}_{3}, \mathrm{ppm}\right): 159.56,148.56,141.44,129.98$, $129.82,128.72,123.98,123.72,82.37,61.10,53.51$, $53.46,45.30$.

\subsection{Synthesis of $M L X_{2}$ complexes $(M=Z n(I I), C d(I I)$} and $\mathrm{Hg}(\mathrm{II})$ and $\left.\mathrm{X}=\mathrm{Cl}^{-}, \mathrm{Br}^{-}, \mathrm{I}^{-}\right)$

Imidazolidine Schiff base ligand (0.369 g, $1 \mathrm{mmol})$ was dissolved in $20 \mathrm{~mL}$ of absolute ethanol and then gradually added to methanolic solution of chloride, bromide and/or iodide salts of zinc (II), cadmium (II) and mercury (II) $(1 \mathrm{mmol})$ and the mixture was continuously stirred at room temperature. The resultant precipitates were filtered off and washed with cooled ethanol and then recrystallized from dichloromethane/ethanol mixture solvent $(1: 1)$ and finally dried on the vacuum apparatus. Some important FT/IR, UV-visible, ${ }^{1}$ HNMR and ${ }^{13} \mathrm{CNMR}$ data are listed in below:

[ZnLCl $\mathbf{Z}_{2}$ ]. IR(KBr, $\left.\mathrm{cm}^{-1}\right):$ 3500(m), 3253(s), 3103(w), 3068(w), 2957(w), 2935(w), 2852(w), 1649(s), 1602(s), 1522(vs), 1348(vs), 1218(w), 1106(w), 1064(w), 1018(w), 916(w), 855(s), 832(s), 747(s), 693(s), 584(w), 492(w).UV-Vis [(DMF), $\lambda(\mathrm{nm})(\varepsilon$, $\left.\mathrm{M}^{-1} \mathrm{~cm}^{-1}\right)$ ]: 279 (20096). ${ }^{1} \mathrm{H}$ NMR (DMSO-d $\left.{ }_{6}, \mathrm{ppm}\right)$ : $8.43(\mathrm{~s}, 1 \mathrm{H}), 8.30(\mathrm{~d}, 2 \mathrm{H}, \mathrm{J}=8.76 \mathrm{~Hz}), 8.11(\mathrm{~d}, 2 \mathrm{H}, \mathrm{J}$ $=8.72 \mathrm{~Hz}), 7.94(\mathrm{~d}, 2 \mathrm{H}, \mathrm{J}=8.88 \mathrm{~Hz}), 7.69(\mathrm{~d}, 2 \mathrm{H}, \mathrm{J}$ $=8.64 \mathrm{~Hz}), 4.41(\mathrm{~s}, 1 \mathrm{H}), 3.90-2.50\left(\mathrm{~m}, 8 \mathrm{H}_{\text {ethylenic }}\right.$ and $\mathrm{H}_{\mathrm{NH}}$ ). ${ }^{13} \mathrm{C}$ NMR (DMSO-d 6 , ppm): 160.03, 149.13, $148.45,147.14,141.59,129.34,128.79,123.88$, 123.05, 81.16, 59.87, 53.08, 52.68, 44.80 . 
[ZnLBr $\mathbf{Z n}_{2}$. IR(KBr, cm $\left.{ }^{-1}\right): 3445(\mathrm{~m}), 3252(\mathrm{~s}), 3102(\mathrm{w})$, 3069(w), 2954(w), 2933(w), 2850(w), 1647(s), 1602(s), 1522(vs), 1347(vs), 1217(w), 1106(w), 1083(w), 1014(w), 916(w), 854(s), 831(s), 746(s), 692(s), 582(w), 491(w).UV-Vis [(DMF), $\lambda(\mathrm{nm})(\varepsilon$, $\left.\mathrm{M}^{-1} \mathrm{~cm}^{-1}\right)$ ]: $279(15586) .{ }^{1} \mathrm{H} \mathrm{NMR}\left(\mathrm{CDCl}_{3}, \mathrm{ppm}\right)$ : 8.70(s, 2H), 8.37(d, 4H, J = 8.80 Hz), 8.14(d, 4H, $\mathrm{J}=8.90 \mathrm{~Hz}), 4.60(\mathrm{~m}, 4 \mathrm{H}), 3.37(\mathrm{~m}, 2 \mathrm{H}), 3.30(\mathrm{~m}, 2 \mathrm{H})$, 3.10(m, 1H). ${ }^{13} \mathrm{C}$ NMR $\left(\mathrm{CDCl}_{3}, \mathrm{ppm}\right): 163.85,155.65$, $145.30,130.49,124.12,59.62,49.65$.

[ZnLI $\mathbf{Z}_{2}$ ]. IR( $\left.\mathrm{KBr}, \mathrm{cm}^{-1}\right):$ 3435(m), 3251(s), 3102(w), 3069(w), 2938(w), 2884(w), 2842(w), 1647(s), 1601(s), 1520(vs), 1438(w), 1346(vs), 1217(w), 1105(w), 1083(w), 1009(w), 934(w), 851(s), 834(m), 746(s), 692(s), 583(w), 479(w).UV-Vis [(DMF), $\lambda(\mathrm{nm})$ $\left.\left(\varepsilon, \mathrm{M}^{-1} \mathrm{~cm}^{-1}\right)\right]: 277(17528) .{ }^{1} \mathrm{H}$ NMR $\left(\mathrm{CDCl}_{3}, \mathrm{ppm}\right)$ : $8.71(\mathrm{~s}, 2 \mathrm{H}), 8.37(\mathrm{~d}, 4 \mathrm{H}, \mathrm{J}=8.84 \mathrm{~Hz}), 8.16(\mathrm{~d}, 4 \mathrm{H}, \mathrm{J}=$ $8.84 \mathrm{~Hz}), 4.06(\mathrm{~m}, 4 \mathrm{H}), 3.31(\mathrm{~m}, 4 \mathrm{H}), 3.14(\mathrm{~m}, 1 \mathrm{H}) .{ }^{13} \mathrm{C}$ NMR $\left(\mathrm{CDCl}_{3}, \mathrm{ppm}\right): 165.95,151.70,140.50,130.79$, $124.02,58.33,48.78$.

[CdLCl ${ }_{2}$ ]. IR(KBr, cm $\left.{ }^{-1}\right):$ 3443(m), 3278(s), 3102(w), 3071(w), 2947(w), 2861(w), 2842(w), 1638(s), 1599(s), 1517(vs), 1444(w), 1347(vs), 1215(w), 1101(w), 1011(w), 941(w), 849(m), 830(m), 747(s), 690(s), 509(w), 479(w).UV-Vis [(DMF), $\lambda(\mathrm{nm})(\varepsilon$, $\left.\mathrm{M}^{-1} \mathrm{~cm}^{-1}\right)$ ]: $274(14802) .{ }^{1} \mathrm{H}$ NMR(DMSO-d $\left.\mathrm{d}_{6}, \mathrm{ppm}\right)$ : $8.63(\mathrm{~s}, 2 \mathrm{H}), 8.29(\mathrm{~d}, 4 \mathrm{H}, \mathrm{J}=8.44 \mathrm{~Hz}), 8.08(\mathrm{~d}, 4 \mathrm{H}, \mathrm{J}=$ $8.48 \mathrm{~Hz}), 3.12(\mathrm{bs}, 4 \mathrm{H}), 2.93(\mathrm{~m}, 4 \mathrm{H}), 3.11(\mathrm{~m}, 1 \mathrm{H}) .{ }^{13} \mathrm{C}$ NMR (DMSO-d 6 , ppm): 161.76, 148.57, 141.21, 129.37, 123.69, 59.14, 49.11.

[CdLI $\mathbf{C}_{2}$ ]. IR(KBr, $\left.\quad \mathrm{cm}^{-1}\right): \quad 3444(\mathrm{~m}), \quad 3275(\mathrm{~s})$, 3100(w), 3071(w), 2921(w), 2870(w), 1639(s), 1601(s), 1520(vs), 1423(w), 1344(vs), 1219(w), 1101(w), 1010(w), 935(w), 851(s), 837(s), 746(s), 693(s), 577(w), 491(w).UV-Vis [(DMF), $\lambda(\mathrm{nm})(\varepsilon$, $\left.\mathrm{M}^{-1} \mathrm{~cm}^{-1}\right)$ ]: $\quad 275(18437) .{ }^{1} \mathrm{H} \quad \mathrm{NMR}\left(\mathrm{CDCl}_{3}, \quad \mathrm{ppm}\right)$ : 8.61(s, 2H), 8.37(d, 4H, J = 8.80 Hz), 8.17(d, 4H, $\mathrm{J}=8.76 \mathrm{~Hz}), 4.60(\mathrm{bt}, 2 \mathrm{H}), 3.88(\mathrm{bd}, 2 \mathrm{H}), 3.38(\mathrm{~m}, 2 \mathrm{H})$, $3.25(\mathrm{~m}, 2 \mathrm{H}), 2.59(\mathrm{~m}, 1 \mathrm{H}) .{ }^{13} \mathrm{C} \mathrm{NMR}\left(\mathrm{CDCl}_{3}, \mathrm{ppm}\right)$ : 165.50, 148.15, 140.48, 131.04, 123.98, 59.73, 49.87.

[HgLI $\mathbf{H}_{2}$ ] IR(KBr, $\left.\mathrm{cm}^{-1}\right)$ : 3446(m), 3215(s), 3102(w), 3074(w), 2901(w), 2881(w), 2852(w), 1639(s), 1600(s), 1519(vs), 1461(w), 1340(vs), 1217(w), 1104(w), 1008(w), 917(w), 849(m), 838(m), 747(s), 686(s), 528(w), 487(w).UV-Vis [(DMF), $\lambda(\mathrm{nm})(\varepsilon$, $\left.\left.\mathrm{M}^{-1} \mathrm{~cm}^{-1}\right)\right]: \quad 279(19540) .{ }^{1} \mathrm{H} \quad \mathrm{NMR}\left(\mathrm{CDCl}_{3}, \mathrm{ppm}\right)$ : $8.59(\mathrm{~s}, 2 \mathrm{H}), 8.33(\mathrm{~d}, 4 \mathrm{H}, \mathrm{J}=8.76 \mathrm{~Hz}), 8.04(\mathrm{~d}, 4 \mathrm{H}, \mathrm{J}=$ $8.80 \mathrm{~Hz}), 3.95(\mathrm{t}, 4 \mathrm{H}), 3.25(\mathrm{bs}, 4 \mathrm{H}), 2.49(\mathrm{bs}, 1 \mathrm{H}) .{ }^{13} \mathrm{C}$
$\mathrm{NMR}\left(\mathrm{CDCl}_{3}, \mathrm{ppm}\right): 163.36,149.54,139.80,129.86$, 124.02, 59.71, 50.25 .

\subsection{Biological activity}

Antibacterial and antifungal activities of ligand and its complexes were tested in vitro. For these antimicrobial investigations, two Gram-negative bacterial strains such as Escherichia coli and Pseudomonas aeruginosa; two Gram-positive bacterial strains such as Staphylococcus aureus and Bacillus subtillis and also the fungus of Candid albicans were selected as a typical fungal strain. The biological activities of all compounds were confirmed by determination of the minimum inhibitory concentration (MIC) values by sample dilution and disk diffusion methods. In MIC method that was used for antibacterial studies, a series of sample solutions with various concentrations (500 to $15.63 \mu \mathrm{g} / \mathrm{mL}$ ) were prepared in DMSO in the sterile test tubes. For the bioassay of the organisms, Muller Hinton broth as basal media was added to the test tubes containing $0.1 \mathrm{~mL}$ of bacterium and then, these test tubes were incubated at $37^{\circ} \mathrm{C}$ for $24 \mathrm{~h}$. For preparation of solid media in disk diffusion method, $15 \mathrm{~mL}$ of nutrient agar for antibacterial and sabouraub dextrose agar for antifungal studies were poured into each petri-plate. Then $0.1 \mathrm{~mL}$ of inoculums of the microorganism (18 h old culture) was swabbed evenly on surface of solid medium and kept for suitable adsorption for $15 \mathrm{~min}$. Sterile paper disks (6 $\mathrm{mm}$ in diameter) were saturated with a desired solution of test compounds that has been prepared in DMSO $(500 \mu \mathrm{g} / \mathrm{mL})$ and then placed on the agar plates. All the plates were incubated at $37^{\circ} \mathrm{C}$ for $24 \mathrm{~h}$ and then the diameters of inhibition zones of the growth were measured by a vernier caliper.

\section{Results and discussion}

The (E)-N-(4-nitrobenzylidene)-2-(2-(4-nitrophenyl) imidazolidin-1-yl) ethaneamine as a new imidazolidine Schiff base ligand was prepared by a condensation reaction between 4-nitrobenzaldehyde and $N^{\prime}$-(2aminoethyl)-ethane-1, 2-diamine in 2:1 molar ratio in dry methanol. Then, some of its new complexes of zinc, cadmium and mercury halides were wellsynthesized and their structures were confirmed by elemental analysis and also by FT/IR, UV-visible, ${ }^{1} \mathrm{H}$ and ${ }^{13} \mathrm{C}$ NMR spectral data. Figure 1 illustrates the suggested structure of free ligand and its complexes. The resultant complexes (tables 1 and 2) are coloured solids and are suggested to be as non-electrolyte complexes as evidenced by their molar conductivities 
(a)

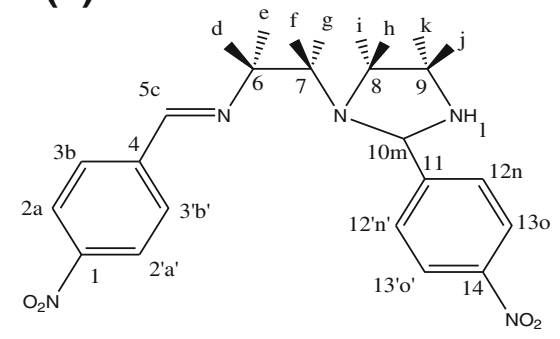

(b)

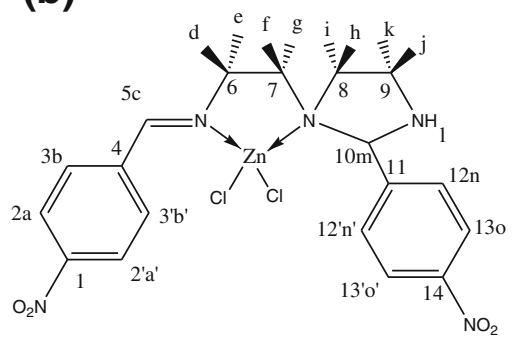

(c)

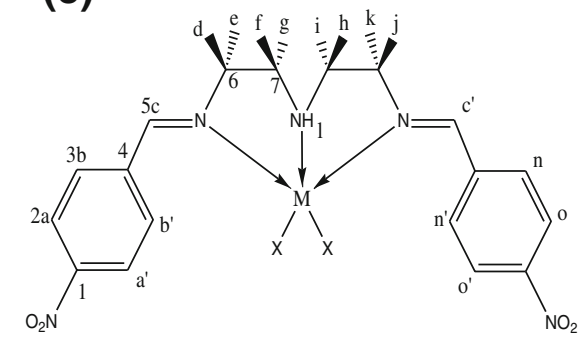

Figure 1. Proposed structure for ligand (a), $\mathrm{ZnLCl}_{2}$ complex (b) and $\mathrm{MLX}_{2}$ wherein $\mathrm{M}=\mathrm{Zn}(\mathrm{II}), \mathrm{X}=\mathrm{Br}^{-}, \mathrm{I}^{-} ; \mathrm{M}=\mathrm{Cd}(\mathrm{II})$, $\mathrm{Hg}$ (II) and $\mathrm{X}=\mathrm{Cl}^{-}, \mathrm{Br}^{-}, \mathrm{I}^{-}$.

$\left(5-28 \Omega^{-1} \mathrm{~cm}^{2} \mathrm{~mol}^{-1}\right)$ of their solutions $\left(10^{-3} \mathrm{M}\right)$ in dry DMF. ${ }^{31}$ All compounds are very stable at room temperature in the solid state. The decomposition temperatures of the complexes were evaluated in the span of $145-241^{\circ} \mathrm{C}$. Elemental analyses and other physical properties of the ligand and its complexes are summarized in table 1 . The results of the elemental analyses are in a good agreement with the proposed formula.

\subsection{Infra-red and electronic spectra}

The characteristic frequencies of the ligand and its complexes spectra are tabulated in table 2. In the IR spectrum of ligand, the vibrational frequencies assigned to the parent amine and aldehyde compounds were not found. On the other hand, appearance of a strong absorption frequency at $1645 \mathrm{~cm}^{-1}$ attributed to the vibrational stretching of the azomethine group, $v(\mathrm{C}=\mathrm{N}),{ }^{32}$ indicates that the titled ligand has been successfully synthesized via a condensation reaction. This absorption frequency is smoothly shifted towards higher frequencies in zinc complexes while shifted to lower frequencies in the cadmium and mercury complexes spectra. Observation of these changes in the vibrational frequencies of azomethine groups proves that the azomethine nitrogen atoms are coordinated to the metal ions. In the ligand spectrum, the stretching vibration of $\mathrm{N}-\mathrm{H}$ is appeared as a broad peak at $3210 \mathrm{~cm}^{-1}$ because of its involvement at probable hydrogen bonding. This vibration is more sharp and shifted to higher vibrational frequencies in the complexes spectra except for the complexes of entries 6 and $8 .{ }^{33}$ The absorption frequencies of aromatic, aliphatic and azomethine $\mathrm{CH}$ bonds are observed at 3101 and 3071, 2941, 2886 and $2848 \mathrm{~cm}^{-1}$, respectively. These absorption peaks have not considerable shift to the higher or lower frequencies in all complexes spectra. The very strong stretching vibrations at 1518 and $1346 \mathrm{~cm}^{-1}$ are attributed to the asymmetric $\left(v_{\text {asym }}\right)$ and symmetric stretching $\left(v_{\text {sym }}\right)$ of $-\mathrm{NO}_{2}$ groups that they shift a few wavenumbers to lower or higher frequencies in the complexes spectra. One of the important absorption frequencies in the complexes spectra confirming their synthesis is the vibrational frequency of $\mathrm{M}-\mathrm{N}$ bond that appeared at the range of $530-584 \mathrm{~cm}^{-1}$ in the complexes spectra. ${ }^{34,35}$ This characteristic absorption peak is not observed in the ligand spectrum (table 2).

Electronic spectra of the ligand and its complexes were recorded in DMF at room temperature and their spectral data including the $\lambda_{\max }$ values are tabulated

Table 1. Analytical and physical data of the imidazolidine Schiff base ligand and its zinc (II), cadmium (II) and mercury (II) complexes.

\begin{tabular}{|c|c|c|c|c|c|c|c|c|}
\hline & \multirow[t]{2}{*}{ Compound } & \multirow[t]{2}{*}{ Colour } & \multirow{2}{*}{$\begin{array}{l}\text { Melting point } \\
\text { (dec.) }\end{array}$} & \multirow[t]{2}{*}{ Yield (\%) } & \multicolumn{3}{|c|}{ Found (calcd.) (\%) } & \multirow{2}{*}{$\begin{array}{c}\Lambda_{\mathrm{M}} \\
\left(\mathrm{cm}^{2} \Omega^{-1} \mathrm{M}^{-1}\right)\end{array}$} \\
\hline & & & & & $\mathrm{C}$ & $\mathrm{N}$ & $\mathrm{H}$ & \\
\hline 1 & Ligand & Cream & $108 *$ & 68 & $58.3(58.53)$ & $18.8(18.96)$ & $5.1(5.18)$ & 5 \\
\hline 2 & $\mathrm{ZnLCl}_{2}$ & Cream & 224 & 75 & $42.3(42.75)$ & $13.5(13.85)$ & $3.4(3.79)$ & 10 \\
\hline 3 & $\mathrm{ZnLBr}_{2}$ & Cream & 235 & 76 & $36.3(36.36)$ & $11.7(11.78)$ & $3.1(3.22)$ & 15 \\
\hline 4 & $\mathrm{ZnLI}_{2}$ & Cream & 241 & 80 & $31.2(31.40)$ & $10.3(10.17)$ & $2.5(2.78)$ & 19 \\
\hline 5 & $\mathrm{CdLCl}_{2}$ & Cream & 220 & 72 & $38.9(39.12)$ & $12.8(12.67)$ & $3.2(3.47)$ & 18 \\
\hline 6 & $\mathrm{CdLI}_{2}$ & Cream & 229 & 85 & $29.2(29.39)$ & $9.5(9.52)$ & $2.4(2.60)$ & 28 \\
\hline 7 & $\mathrm{HgLI}_{2}$ & Cream & 145 & 80 & $26.1(26.24)$ & $8.4(8.50)$ & $2.2(2.32)$ & 13 \\
\hline
\end{tabular}

*melting point 
Table 2. Vibrational $\left(\mathrm{cm}^{-1}\right)$ and electronic $(\mathrm{nm})$ spectral data of the imidazolidine Schiff base ligand and its complexes.

\begin{tabular}{ccccccccccc}
\hline & Compound & $v N H$ & $v \mathrm{CH}_{\text {arom }}$ & $v \mathrm{CH}_{\text {aliph }}$ & $v \mathrm{CH}_{\text {imin }}$ & $v \mathrm{C}=\mathrm{N}$ & $v \mathrm{C}=\mathrm{C}$ & $v\left(-\mathrm{NO}_{2}\right)$ & $v \mathrm{M}-\mathrm{N}$ & $\lambda_{\max }$ \\
\hline 1 & Ligand & 3210 & 3101,3071 & 2941 & 2886,2848 & 1645 & 1601 & 1518,1346 & - & 278 \\
2 & $\mathrm{ZnLCl}_{2}$ & 3253 & 3103,3068 & 2957,2935 & 2852 & 1649 & 1602 & 1522,1348 & 584 & 279 \\
3 & $\mathrm{ZnLBr}_{2}$ & 3252 & 3102,3069 & 2954,2933 & 2850 & 1647 & 1602 & 1522,1347 & 582 & 279 \\
4 & $\mathrm{ZnLI}_{2}$ & 3251 & 3102,3069 & 2938 & 2884,2842 & 1647 & 1601 & 1520,1346 & 583 & 277 \\
5 & $\mathrm{CdLCl}_{2}$ & 3278 & 3102,3071 & 2947 & 2861,2842 & 1638 & 1599 & 1517,1347 & 581 & 274 \\
6 & $\mathrm{CdLI}_{2}$ & 3275 & 3100,3071 & 2921 & 2870 & 1639 & 1601 & 1520,1344 & 577 & 275 \\
7 & $\mathrm{HgLI}_{2}$ & 3214 & 3102,3074 & 2901 & 2881,2852 & 1639 & 1600 & 1519,1340 & 571 & 279 \\
\hline
\end{tabular}

in table 2. In the UV-visible spectrum of the ligand, two types of internal electronic transition (IT) assigning to $\pi-\pi^{*}$ electron transfer of aromatic rings and $\pi-\pi^{*}$ transition localized within the azomethine chromophores are expected. Though it seems that these absorption bands are overlapped with each other and therefore one absorption band is appeared at $278 \mathrm{~nm}$ in the electronic spectrum of the ligand. This absorption band has not considerably changed in the electronic spectra of the complexes. Electronic configuration of IIB transition metal ion is $\mathrm{d}^{10}$ and therefore the $\mathrm{d}-\mathrm{d}$ electronic transition are not expected for them. In the electronic spectra of the titled complexes, the bands of charge transfer transition (MLCT) were also not observed probably due to its overlap with $\pi-\pi^{*}$ electronic transitions of the ligand.

\section{$3.2{ }^{1} H$ and ${ }^{13} C$ NMR spectra}

The ${ }^{1} \mathrm{H}$ and ${ }^{13} \mathrm{C}$ NMR spectral data of the ligand and its metal complexes have been listed in the section 2.3. The ${ }^{1} \mathrm{H}$ NMR of ligand, $\mathrm{ZnLCl}_{2}$ and $\mathrm{HgLI}_{2}$ as typical spectra are exhibited in figure 2 and other spectra are found as supplementary information (figures S1$\mathrm{S} 12)$. The spectral data based on figure 1 show that the structure of free ligand and coordinated one in $\mathrm{ZnLCl}_{2}$ complex are not symmetric. Existence of an imidazolidine ring in the structure of ligand both in free form and in $\mathrm{ZnLCl}_{2}$ complex is well-confirmed by a signal appeared at 4.40 and $4.41 \mathrm{ppm}$ assigned to imidazolidine $\mathrm{C}-\mathrm{H}$ and also by a signal at 82.37 and $81.16 \mathrm{ppm}$ attributed to $\mathrm{C}_{10}$ of imidazolidine ring in ${ }^{1} \mathrm{H}$ and ${ }^{13} \mathrm{C}$ NMR spectra of ligand and its $\mathrm{ZnLCl}_{2}$ complex, respectively. ${ }^{36}$ These signals are not observed at the ${ }^{1} \mathrm{H}$ and ${ }^{13} \mathrm{C}$ NMR spectra of other Schiff base complexes. According to ${ }^{1} \mathrm{H}$ NMR spectrum of ligand, the signal of proton resonance of azomethine group $\left(\mathrm{H}_{\mathrm{c}}\right)$ as a characteristic group of Schiff base compound is appeared at $8.33 \mathrm{ppm}$ as a singlet peak. ${ }^{37}$ Due to binding of the azomethine nitrogen to metal centres, the azomethine proton is more deshielded so that its signal shifts to downfield region in the complexes spectra.
In the spectra of the ligand and $\mathrm{ZnLCl}_{2}$ complex, the signal of $\mathrm{H}_{\mathrm{NH}}$ is overlapped by the signals of ethylenic hydrogens and appeared at the range of 2.6-2.78 ppm and $3.2 \mathrm{ppm}$, respectively. ${ }^{36}$ In the ${ }^{1} \mathrm{H}$ NMR spectra of other complexes, this signal was observed in the range of 2.49-3.14 ppm because of the structural change of ligand in other complexes with respect to free ligand and $\mathrm{ZnLCl}_{2}$ complex. The hydrogens of aromatic rings in the ${ }^{1} \mathrm{H}$ NMR spectrum of ligand were appeared in the range of 7.69 to $8.30 \mathrm{ppm} ; \mathrm{H}_{\mathrm{a} \text { and a }}$ protons were found at $8.30 \mathrm{ppm}$ as doublet signal with $\mathrm{J}=8.76 \mathrm{~Hz}$ due to coupling with hydrogens of $\mathrm{H}_{\mathrm{b}}$ and $\mathrm{b}^{\prime}$. Protons of $\mathrm{H}_{\mathrm{o} \text { and } \mathrm{o}^{\prime}}$ were appeared at $8.18 \mathrm{ppm}$ as a doublet peak due to coupling with hydrogens of $\mathrm{H}_{\mathrm{n}}$ and $\mathrm{n}^{\prime}$. Two doublet peaks at 7.88 and $7.69 \mathrm{ppm}$ with $\mathrm{J}=8.8 \mathrm{~Hz}$

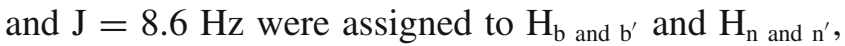
respectively. The signals of the ethylenic hydrogens were appeared at 2.61-3.76 ppm range as eight individual multiplet peaks due to formation of imidazolidine ring leading to the asymmetrical character in ligand structure. In the ${ }^{1} \mathrm{H}$ NMR spectra of the complexes, the signals of aromatic ring hydrogens were observed at 7.69-8.37 ppm and the signals of ethylenic hydrogens were appeared at $2.50-4.60 \mathrm{ppm}$ range. ${ }^{1} \mathrm{H}$ NMR spectra of the complexes showed the signals of $\mathrm{H}_{\mathrm{a} \text { and } \mathrm{a}^{\prime}}$ and $\mathrm{H}_{\mathrm{o} \text { and o }}$ as doublet peaks in the range of 8.29-8.37 ppm except for entry 2 . The same pattern was observed for $\mathrm{H}_{\mathrm{b} \text { and } \mathrm{b}^{\prime}}$ and $\mathrm{H}_{\mathrm{n} \text { and } \mathrm{n}^{\prime}}$ at 8.04-8.17 ppm. The ethylenic hydrogens of $\mathrm{H}_{\mathrm{e}, \mathrm{d}, \mathrm{j}, \mathrm{k}}$ were found as a multiplet peaks at 3.12-4.60 ppm range. For the complex of entry 6, $\mathrm{H}_{\mathrm{d} \text { and } \mathrm{j}}$ and $\mathrm{H}_{\mathrm{e}}$ and $\mathrm{k}$ showed different chemical shifts such that their peaks were appeared at $4.04 \mathrm{ppm}$ and $3.88 \mathrm{ppm}$ as a broad triplet and doublet, respectively. The ${ }^{1} \mathrm{H}$ NMR spectra of entries 4,5 and 7 included multiplet peaks at 2.93-3.31 ppm range for $\mathrm{H}_{\mathrm{f}, \mathrm{g}, \mathrm{h}, \mathrm{i}}$. In the complexes spectra of entries 3 and 6 , the signals

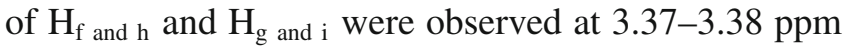
and $3.25-3.30 \mathrm{ppm}$ as multiplet peaks, respectively. In some cases, it seems that the chemical shifts of ethylenic hydrogens are affected by the spatial position of $\mathrm{H}_{\mathrm{NH}}$ in the complexes structures and therefore are appeared at different chemical shifts with respect to 

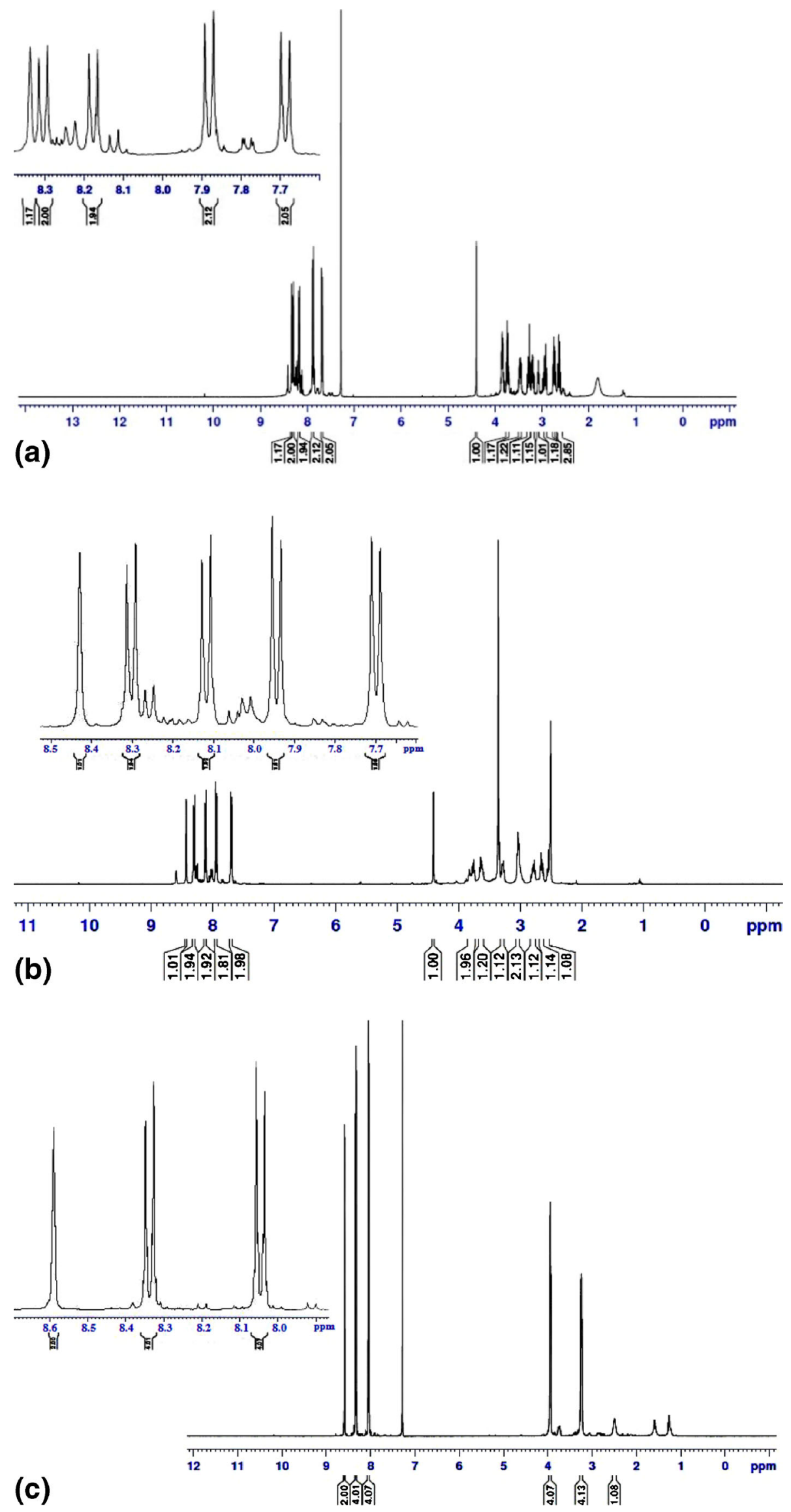

Figure 2. ${ }^{1} \mathrm{H} \mathrm{NMR}(\mathbf{a}, \mathbf{b}$ and $\mathbf{c})$ of the ligand, $\mathrm{ZnLCl}_{2}$ and $\mathrm{HgLI}_{2}$, respectively. 
TMS. The ${ }^{13} \mathrm{C}$ NMR spectrum of the ligand showed the azomethine carbon $\left(\mathrm{C}_{5}\right)$ resonance as functional group at $159.56 \mathrm{ppm}$. This peak is shifted to 160.03-165.95 ppm in its complexes suggesting well-coordination of the azomethine nitrogens to metal ions. In the ${ }^{13} \mathrm{C}$ NMR spectrum of the ligand, the resonance signals of aromatic carbons are suggested to be appeared at $148.56\left(\mathrm{C}_{1,14}\right), 141.44\left(\mathrm{C}_{4,11}\right)$, $129.98\left(\mathrm{C}_{12}\right), 129.82\left(\mathrm{C}_{12^{\prime}}\right), 128.72\left(\mathrm{C}_{3,3^{\prime}}\right), 123.98\left(\mathrm{C}_{2,2^{\prime}}\right)$, $123.72\left(\mathrm{C}_{13,13^{\prime}}\right)$; imidazolidine carbon $\left(\mathrm{C}_{10}\right)$ is found at $82.37 \mathrm{ppm}$ and the ethylenic carbons resonance are observed as four individual peaks at $61.10\left(\mathrm{C}_{8}\right)$, 53.51 $\left(\mathrm{C}_{6}\right), 53.46\left(\mathrm{C}_{9}\right)$ and $45.30\left(\mathrm{C}_{7}\right)$ ppm. In the ${ }^{13} \mathrm{C}$ NMR spectrum of $\mathrm{ZnLCl}_{2}$ complex containing the retained structure of ligand, the peaks of aromatic ring carbons and imidazolidine carbon may be assigned as $149.13\left(\mathrm{C}_{1}\right), \quad 148.45\left(\mathrm{C}_{14}\right), \quad 147.14\left(\mathrm{C}_{4}\right)$, $141.59\left(\mathrm{C}_{11}\right), 129.34\left(\mathrm{C}_{12,12^{\prime}}\right), 128.79\left(\mathrm{C}_{3,3^{\prime}}\right), 123.88\left(\mathrm{C}_{2,2^{\prime}}\right)$, $123.05\left(\mathrm{C}_{13,13^{\prime}}\right)$ and $81.16\left(\mathrm{C}_{10}\right)$ ppm, respectively. On the other hand, the ethylenic carbons signals are observed as four characteristic peaks at $59.87\left(\mathrm{C}_{8}\right)$, 53.08 $\left(\mathrm{C}_{6}\right), 52.68\left(\mathrm{C}_{9}\right)$ and $44.80\left(\mathrm{C}_{7}\right) \mathrm{ppm}$. In the ${ }^{13} \mathrm{C}$ NMR spectra of other complexes, seven signals of carbon resonances assigned to seven types of carbons in the symmetric structures of them are obviously observed. For these complexes, the azomethine carbon signals appeared at 161.76-165.95 ppm range show a downfield shift with respect to one in free ligand. Finally, the signals attributed to $\left(\mathrm{C}_{1}\right),\left(\mathrm{C}_{4}\right)$, $\left(\mathrm{C}_{3}\right),\left(\mathrm{C}_{2}\right),\left(\mathrm{C}_{6}\right)$ and $\left(\mathrm{C}_{7}\right)$ are found in the ranges of $148.15-155.65,139.80-145.30,129.37-131.04$, 123.69-124.12, 58.33-58.73 and 48.78-50.25 ppm in the complexes spectra, respectively.

\subsection{Coordination mode}

With regard to spectral data, it is suggested that the ligand is formed as imidazolidine Schiff base (figure 1a) not as a simple bis-azomethine ligand. This type of Schiff base ligand has been previously reported by Yue et $a l .{ }^{36}$ The titled imidazolidine Schiff base is coordinated to zinc chloride without ring opening of the imidazolidine and acts as a bidentate $\mathrm{N}_{2}$-ligand that along with chloride anions forms pseudo-tetrahedral geometry around the zinc ion. Coordination of the ligand to other metal salts is accompanied with imidazolidine ring opening so that the ligand is coordinated to metal centers as a tridentate bis-azomethine amine ligand such that five coordinated complexes are formed along with halide anions similar to some other previous reports. ${ }^{38,39}$ The change in coordination mode of the ligand may be due to electronic and steric effect of metal ion and its halide anions so that where the metal ion is zinc and halide is chloride, the coordination of imidazolidine Schiff base ligand is possible as shown in figure $1 \mathrm{~b}$ but when the metal ion and/or halide anions is changed to more voluminous and polarizable ones, the electronic and steric effects prevent the coordination of ligand as imidazolidine form. Therefore, imidazolidine ring of ligand is opened during the coordination of ligand as shown in figure 1c.

\subsection{Thermal investigation}

Thermal behaviour (TG/DTA) of the titled compounds were investigated at the heating rate of $10\left({ }^{\circ} \mathrm{C} / \mathrm{min}\right)$ under nitrogen atmosphere from room temperature to $600^{\circ} \mathrm{C}$. TG/DTA plots of the ligand, zinc and mercury iodide complexes as illustrative diagrams in figure 3 . Thermal analysis data including thermal decomposition steps, mass loss (\%) and thermodynamic activation parameters of each decomposition steps of the ligand and its complexes have been derived and tabulated in table 3 based on TG/DTA plots.

The TG diagrams confirm the absence of water molecules in the complex structures. The TG/DTA plots of ligand and its complexes indicate that they are decomposed in four successive thermal steps except for $\mathrm{ZnLBr}_{2}$ that is decomposed in three thermal steps. First thermal step in the TG plots of all compounds may be assigned to thermal elimination of nitro-groups. In the next thermal steps, the ligand and its complexes lose $38.58-81.9 \%$ of total mass up to $600^{\circ} \mathrm{C}$ attributed to other organic segments as suggested in table 3 .

Moreover, the thermodynamic activation parameters of thermal decomposition steps of the ligand and its complexes including Arrhenius constant (A), activation energy $\left(\mathrm{E}^{*}\right)$, enthalpy $\left(\Delta \mathrm{H}^{*}\right)$, entropy $\left(\Delta \mathrm{S}^{*}\right)$ and Gibbs free energy $\left(\Delta \mathrm{G}^{*}\right)$ of thermal steps were evaluated using Coats-Redfern relation based on TG plots. ${ }^{40,41}$ Activation parameters evaluation of the ligand and its complexes may be carried out to suggest the thermal stability of them. The resultant values showed that the activation energies $\left(\mathrm{E}^{*}\right)$ in the different steps of thermal decomposition processes are found in the range of $22.57-352.69 \mathrm{kJmol}^{-1}$ indicating relatively high thermal stability of the compounds. The values of the activation entropy $\left(\Delta S^{*}\right)$ are evaluated as negative numbers for all thermal decomposition steps of compounds except for the first thermal steps of ligand, zinc and cadmium iodide complexes and are found in the range of $-266-409 \mathrm{Jmol}^{-1} \mathrm{k}^{-1}$. The negative values suggest an associated mechanism at rate determining step of thermal decomposition process similar to many reports in the literature in this matter. All evaluated $\Delta H^{*}$ and $\Delta G^{*}$ values for the compounds are positive 

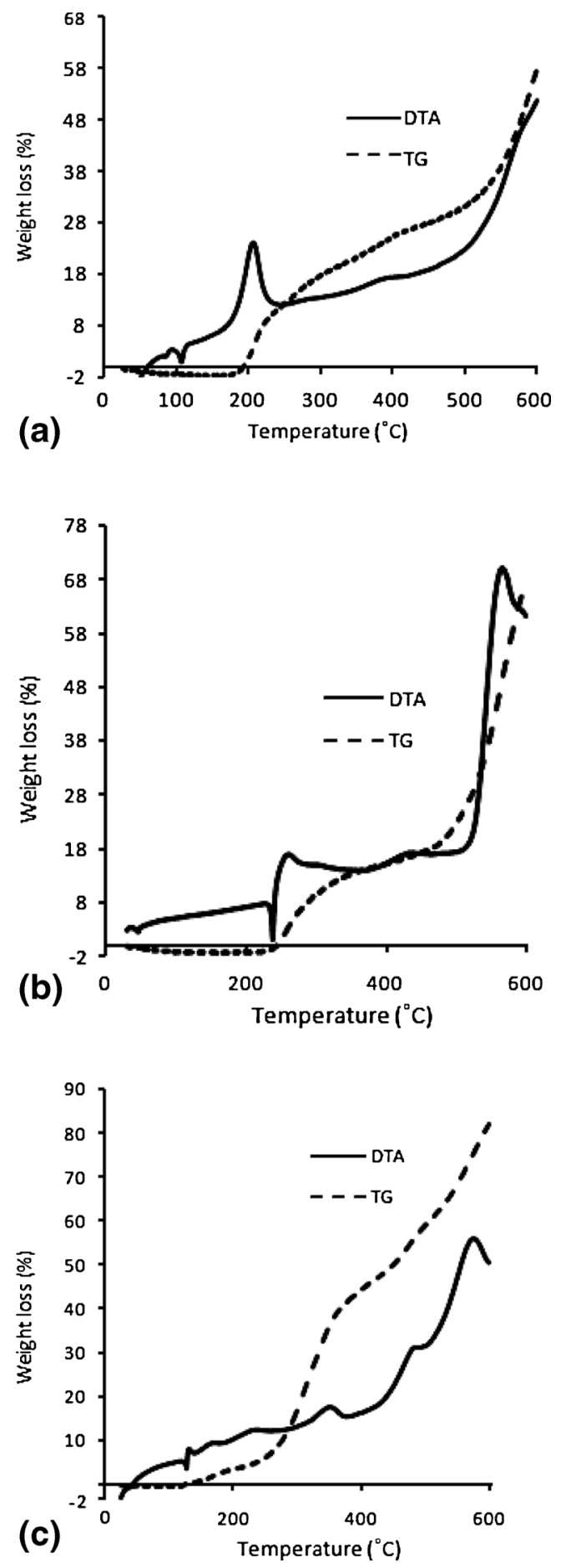

Figure 3. TG/DTA diagrams of ligand (a), zinc iodide complex (b) and mercury iodide complex (c).

numbers in the range of 17.5 to $348.53 \mathrm{kJmol}^{-1}$ and 134 to $249 \mathrm{kJmol}^{-1}$, respectively indicating endothermic character of all thermal decomposition steps.

\subsection{Cyclic voltammetry}

The electrochemical behaviour of the Schiff base ligand and its complexes $\left(10^{-3} \mathrm{M}\right)$ were studied by cyclic voltammetry technique in the potential window of -2.00 to $0.5 \mathrm{~V}$ in dry acetonitrile solution containing $(n-\mathrm{Bu})_{4} \mathrm{NPF}_{6}(\mathrm{TBAHP})$ as supporting electrolyte $\left(10^{-3} \mathrm{M}\right)$. The cyclic voltammogarms of ligand, zinc chloride and mercury iodide complexes have been illustrated in figure 4 as representative diagrams while all electrochemical data considered as potential window have been tabulated in table 4. Cyclic voltammogram of ligand showed four cathodic and two anodic potential peaks. The cathodic peaks $\left.\mathrm{E}_{\mathrm{pc}}\right)$ were found at $-0.81 \mathrm{~V}(\mathrm{I}),-0.95 \mathrm{~V}(\mathrm{II}),-1.35 \mathrm{~V}$ (III) and $-1.64 \mathrm{~V}(\mathrm{IV})$ while two anodic peaks $\mathrm{E}_{\left(\mathrm{E}_{\mathrm{pc}}\right)}$ were appeared at $-0.74 \mathrm{~V}$ and $-0.87 \mathrm{~V}$ in relative to I and II cathodic potential peaks. The cathodic peaks appeared at $-0.81 \mathrm{~V}$ and $-0.95 \mathrm{~V}$ may be corresponded to the reduction of two different nitro-groups in the ligand structure (as shown in figure 1) to nitro-anion radicals and then to nitroso groups in one step, respectively. These reduction steps are quasi-reversibly followed (potential difference $\left(\Delta \mathrm{E}_{\mathrm{p}}\right)$ values are $0.070 \mathrm{~V}$ and $0.080 \mathrm{~V}$, respectively) by two anodic peaks as mentioned above. The irreversible cathodic peaks appeared at $-1.35 \mathrm{~V}$ and $-1.64 \mathrm{~V}$ may be attributed to the reduction of the nitroso groups to the hydroxyl amine and then to amine groups, respectively. ${ }^{42,43}$ Based on electrochemical data in table 4 , it seems that in zinc chloride and bromide complexes, the reduction of one nitrogroup to nitroso group have occurred via two different steps (peaks IIa, IIb) (instead of one step observed in free ligand as mentioned above) with anodic and cathodic shifts for (I, IIa) and IIb with respect to free ligand as shown in table 4 while other reduction peaks (III and IV) are seen in a model similar to free ligand. The electrochemical behaviour of coordinated ligand in zinc iodide is similar to free ligand but with an anodic shift in its potential values. The anodic shift in potential values of ligand in zinc complexes is due to its coordination to metal centre and then induction of positive charge on ligand structure that facilitates its redox behaviour. Voltammograms of cadmium chloride and cadmium iodide complexes also show the same electrochemical behaviour as observed for the free ligand but with a cathodic shift in redox potential values confirming a well-coordination of ligand. The cathodic shift may be because of an induction of negative charge on ligand structural surface because of an efficient $\pi$ - back bonding from cadmium ion as an electron-rich metal ion to ligand $\pi^{*} \operatorname{orbitals}\left(\pi^{*}\right.$ of iminic bond $(\mathrm{C}=\mathrm{N})$ ) after initial coordination. ${ }^{44-46}$ For mercury iodide complex, a electrochemical behaviour similar to coordinated ligand in the cadmium complexes is observed but the fourth reduction is not observed suggesting a high cathodic shift to out of studied potential window. 
Table 3. Thermal analysis data including thermal decomposition steps, mass loss (\%) and thermodynamic activation parameters of thermal steps of ligand and its complexes.

\begin{tabular}{|c|c|c|c|c|c|c|c|c|}
\hline Compound & $\begin{array}{l}\text { Thermal } \\
\text { step }\left({ }^{\circ} \mathrm{C}\right)\end{array}$ & $\begin{array}{c}\text { Mass } \\
\operatorname{loss}(\%)\end{array}$ & $\begin{array}{c}\text { Total } \\
\text { mass } \\
\operatorname{loss}(\%)\end{array}$ & $\mathrm{E}^{*}\left(\mathrm{kJmol}^{-1}\right)$ & $\mathrm{A}\left(\mathrm{s}^{-1}\right)$ & $\Delta \mathrm{S}^{*}\left(\mathrm{kJmol}^{-1}\right)$ & $\Delta \mathrm{H}^{*}\left(\mathrm{kJmol}^{-1}\right.$ & $\Delta \mathrm{G}^{*}\left(\mathrm{kJmol}^{-1}\right)$ \\
\hline \multirow[t]{4}{*}{ Ligand } & $160-240$ & 11.3 & \multirow[t]{4}{*}{56.3} & 239.34 & $5.32 \times 10^{23}$ & $2.05 \times 10^{2}$ & 235.39 & $1.38 \times 10^{2}$ \\
\hline & $240-340$ & 8.3 & & 33.66 & 2.99 & $-2.41 \times 10^{2}$ & 29.08 & $1.62 \times 10^{2}$ \\
\hline & $340-470$ & 8.5 & & 54.42 & $4.61 \times 10^{1}$ & $-2.20 \times 10^{2}$ & 48.84 & $1.96 \times 10^{2}$ \\
\hline & $470-600$ & 28.2 & & 96.25 & $1.99 \times 10^{3}$ & $-1.90 \times 10^{2}$ & 89.26 & $2.49 \times 10^{2}$ \\
\hline \multirow[t]{3}{*}{$\mathrm{ZnLBr}_{2}$} & $200-310$ & 11.04 & \multirow[t]{3}{*}{38.58} & 129.66 & $1.95 \times 10^{10}$ & $-5.26 \times 10^{1}$ & 125.33 & $1.53 \times 10^{2}$ \\
\hline & $310-430$ & 3.04 & & 64.66 & $6.16 \times 10^{2}$ & $-1.98 \times 10^{2}$ & 59.22 & $1.89 \times 10^{2}$ \\
\hline & $430-600$ & 24.5 & & 108.37 & $1.18 \times 10^{4}$ & $-1.76 \times 10^{2}$ & 101.39 & $2.49 \times 10^{2}$ \\
\hline \multirow[t]{4}{*}{$\mathrm{ZnLI}_{2}$} & $210-285$ & 9.04 & \multirow[t]{4}{*}{58.13} & 175.70 & $6.75 \times 10^{14}$ & $3.42 \times 10^{1}$ & 171.31 & $1.53 \times 10^{2}$ \\
\hline & $285-340$ & 4.9 & & 54.21 & $2.23 \times 10^{2}$ & $-2.06 \times 10^{2}$ & 49.34 & $1.70 \times 102$ \\
\hline & $340-415$ & 3.1 & & 31.15 & $8.06 \times 10^{-1}$ & $-2.53 \times 10^{2}$ & 25.83 & $1.88 \times 10^{2}$ \\
\hline & $415-600$ & 51.09 & & 135.91 & $7.03 \times 10^{5}$ & $-1.42 \times 10^{2}$ & 128.96 & $2.47 \times 10^{2}$ \\
\hline \multirow[t]{4}{*}{$\mathrm{CdLCl}_{2}$} & $180-275$ & 13.88 & \multirow[t]{4}{*}{46.38} & 94.95 & $1.90 \times 10^{7}$ & $-1.10 \times 10^{2}$ & 90.85 & $1.45 \times 10^{2}$ \\
\hline & $275-360$ & 4.00 & & 26.21 & $5.63 \times 10^{-1}$ & $-2.55 \times 10^{2}$ & 21.44 & $1.68 \times 10^{2}$ \\
\hline & $360-455$ & 3.00 & & 100.50 & $3.03 \times 10^{5}$ & $-1.47 \times 10^{2}$ & 94.77 & $1.96 \times 10^{2}$ \\
\hline & $455-600$ & 25.5 & & 46.47 & $8.50 \times 10^{-1}$ & $-2.55 \times 10^{2}$ & 39.82 & $2.43 \times 10^{2}$ \\
\hline \multirow[t]{4}{*}{$\mathrm{CdLI}_{2}$} & $210-265$ & 8.13 & \multirow[t]{4}{*}{59.46} & 352.69 & $2.29 \times 10^{34}$ & $4.09 \times 10^{2}$ & 348.53 & $1.44 \times 10^{2}$ \\
\hline & $265-380$ & 8.43 & & 22.57 & $1.69 \times 10^{-1}$ & $-2.66 \times 10^{2}$ & 17.57 & $1.77 \times 10^{2}$ \\
\hline & $380-500$ & 15.00 & & 48.10 & 3.79 & $-2.41 \times 10^{2}$ & 42.04 & $2.18 \times 10^{2}$ \\
\hline & $500-600$ & 27.9 & & 79.10 & $1.92 \times 10^{2}$ & $-2.10 \times 10^{2}$ & 72.22 & $2.46 \times 10^{2}$ \\
\hline \multirow[t]{4}{*}{$\mathrm{HgLI}_{2}$} & $120-230$ & 4.79 & \multirow[t]{4}{*}{81.90} & 39.31 & $5.85 \times 10^{1}$ & $-2.15 \times 10^{2}$ & 35.51 & $1.34 \times 10^{2}$ \\
\hline & $230-435$ & 43.41 & & 34.98 & 1.35 & $-2.49 \times 10^{2}$ & 29.69 & $1.88 \times 10^{2}$ \\
\hline & $435-520$ & 14.10 & & 50.84 & 7.68 & $-2.36 \times 10^{2}$ & 44.59 & $2.22 \times 10^{2}$ \\
\hline & $520-600$ & 19.6 & & 67.34 & $3.57 \times 10^{1}$ & $-2.24 \times 10^{2}$ & 60.34 & $2.49 \times 10^{2}$ \\
\hline
\end{tabular}

Furthermore, two new reversible redox potentials are observed at mercury iodide complex voltammogram as $\mathrm{I}^{\prime}$ and $\mathrm{II}^{\prime}$ peaks that may be attributed to $\mathrm{Hg}(\mathrm{II}) /(\mathrm{I})$ and $\mathrm{Hg}(\mathrm{I}) /(0)$ redox pairs, respectively.

\subsection{Antibacterial and antifungal activity}

The Schiff base ligand and its metal complexes were tested in vitro for their antibacterial activities against

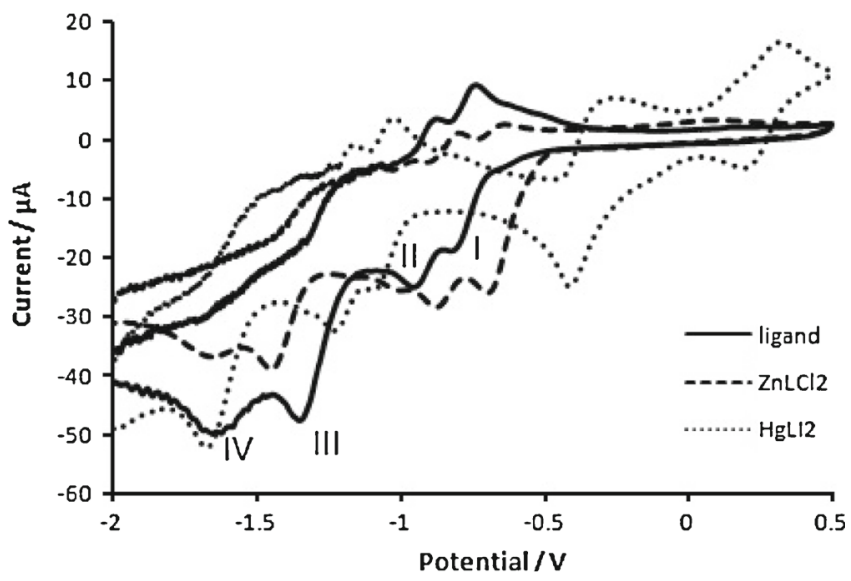

Figure 4. The cyclic voltammograms of ligand, $\mathrm{ZnLCl}_{2}$ and $\mathrm{HgLI}_{2}$ in dry acetonitrile. two Gram-negative and two Gram-positive bacterial strains including Escherichia coli, Pseudomonas aeruginosa, Staphylococcus aureus and Bacillus subtillis bacteria and also for their inhibitory effects on the growth of Candid albicans using disc diffusion and MIC methods. The antibacterial activities of the ligand and its complexes as inhibition zone $(\mathrm{mm})$ of the bacterial and fungal growth have been classified in table 5 and also depicted as column diagram in figure 5 . The solutions with concentration of $500 \mu \mathrm{g} / \mathrm{mL}$ of Schiff base ligand and its complexes in DMSO were applied in disc diffusion technique. The effective material on each disk was estimated to be $25 \mu \mathrm{g}$. The MIC method was also peformed for all the compounds by use of the sample solutions with $15.63,31.25,62.50,125$, $250,500 \mu \mathrm{g} / \mathrm{mL}$ concentrations. The results showed that the synthesized complexes are more antimicrobial active as compared with their parent Schiff base ligand against the same bacteria and fungi under the same experimental conditions. An increase in the inhibitory effect of the complexes as compared with the free ligand may be discussed based on Overtone's concept and Tweedy's chelation theory. ${ }^{47,48}$ The cell membrane has been made from lipid layers that are permeable only for lipid-soluble materials. The antibacterial activity of 
Table 4. The cyclic voltammetric data of imidazolidine Schiff base ligand and its complexes.

\begin{tabular}{|c|c|c|c|c|}
\hline Compound & Peak & $\mathrm{E}_{\mathrm{pc}}(\mathrm{V})$ & $\mathrm{E}_{\mathrm{pa}}(\mathrm{V})$ & $\Delta \mathrm{E}_{\mathrm{p}}(\mathrm{V})$ \\
\hline \multirow{4}{*}{ Ligand } & I & -0.81 & -0.74 & 0.070 \\
\hline & II & -0.95 & -0.87 & 0.080 \\
\hline & III & -1.35 & - & - \\
\hline & IV & -1.64 & - & - \\
\hline \multirow[t]{5}{*}{$\mathrm{ZnLCl}_{2}$} & I & -0.69 & -0.64 & 0.050 \\
\hline & IIa & -0.88 & -0.79 & 0.090 \\
\hline & IIb & -1.01 & -0.95 & 0.060 \\
\hline & III & -1.45 & - & - \\
\hline & V & -1.65 & - & - \\
\hline \multirow{5}{*}{$\mathrm{ZnLBr}_{2}$} & I & -0.61 & -0.51 & 0.100 \\
\hline & IIa & -0.88 & -0.76 & 0.120 \\
\hline & IIb & -1.02 & -0.91 & 0.110 \\
\hline & III & -1.5 & - & - \\
\hline & IV & -1.77 & - & - \\
\hline \multirow[t]{4}{*}{$\mathrm{ZnLI}_{2}$} & I & -0.76 & -0.67 & 0.090 \\
\hline & II & -0.89 & -0.82 & 0.070 \\
\hline & III & -1.45 & - & - \\
\hline & IV & -1.6 & - & - \\
\hline \multirow[t]{4}{*}{$\mathrm{CdLCl}_{2}$} & I & -0.88 & -0.79 & 0.090 \\
\hline & II & -0.99 & -0.94 & 0.050 \\
\hline & III & -1.45 & - & - \\
\hline & IV & -1.76 & - & - \\
\hline \multirow{4}{*}{$\mathrm{CdLI}_{2}$} & I & -0.92 & -0.83 & 0.090 \\
\hline & II & -1.05 & -0.98 & 0.070 \\
\hline & III & -1.66 & - & - \\
\hline & IV & -1.83 & - & - \\
\hline \multirow[t]{5}{*}{$\mathrm{HgLI}_{2}$} & $\mathrm{I}^{\prime}$ & 0.2 & 0.32 & 0.120 \\
\hline & $\mathrm{II}^{\prime}$ & -0.41 & -0.29 & 0.120 \\
\hline & I & -1.09 & -1.02 & 0.070 \\
\hline & II & -1.23 & -1.16 & 0.070 \\
\hline & III & -1.67 & - & - \\
\hline
\end{tabular}

a compound is depended on its liposolubility character. After coordination of organic ligand to metal centre, the polarity of the metal ion considerably is reduced due to overlap of its valence orbitals with the ligand orbitals. This leads to a decrease in positive charge of metal ion and $\pi$-electron delocalization within whole of the ligand chelating ring that would certainly enhance the lipophilic character of the central metal ion. The increased lipophilicity character causes more diffusion of the complexes into cell membrane and blocks the

Table 5. Antibacterial and antifungal activities of $25 \mu \mathrm{g} / \mathrm{disk}$ of the imidazolidine Schiff bases ligand and its complexes based on inhibition zone of the bacterial and fungal growth $(\mathrm{mm})$ and their MIC values $(\mu \mathrm{g} / \mathrm{mL})$.

\begin{tabular}{|c|c|c|c|c|c|c|c|c|c|}
\hline \multirow{3}{*}{ Compound } & \multicolumn{4}{|c|}{ Gram-negative bacteria } & \multicolumn{4}{|c|}{ Gram-positive bacteria } & \multirow{3}{*}{$\begin{array}{c}\text { Candida } \\
\frac{\text { albicans }}{\text { zone }} \\
(\mathrm{mm})\end{array}$} \\
\hline & \multicolumn{2}{|c|}{ Escherichia coli } & \multicolumn{2}{|c|}{ Pseudomonas aereuguinosa } & \multicolumn{2}{|c|}{ Bacillus subtillis } & \multicolumn{2}{|c|}{ Staphylococcus aureus } & \\
\hline & $\begin{array}{c}\text { MIC } \\
(\mu \mathrm{g} / \mathrm{mL})\end{array}$ & $\begin{array}{l}\text { Zone } \\
(\mathrm{mm})\end{array}$ & $\begin{array}{c}\text { MIC } \\
(\mu \mathrm{g} / \mathrm{mL})\end{array}$ & $\begin{array}{l}\text { zone } \\
(\mathrm{mm})\end{array}$ & $\begin{array}{c}\text { MIC } \\
(\mu \mathrm{g} / \mathrm{mL})\end{array}$ & $\begin{array}{l}\text { zone } \\
(\mathrm{mm})\end{array}$ & $\begin{array}{c}\text { MIC } \\
(\mu \mathrm{g} / \mathrm{mL})\end{array}$ & $\begin{array}{l}\text { zone } \\
(\mathrm{mm})\end{array}$ & \\
\hline Ligand & 500 & 11.50 & 500 & 6.80 & 500 & 14.46 & 500 & 10.00 & 17.40 \\
\hline $\mathrm{ZnLCl}_{2}$ & 250 & 15.50 & 500 & 8.44 & 250 & 17.00 & 250 & 12.00 & 24.80 \\
\hline $\mathrm{ZnLBr}_{2}$ & 500 & 12.20 & 500 & 7.90 & 500 & 15.00 & 500 & 11.50 & 21.80 \\
\hline $\mathrm{ZnLI}_{2}$ & 250 & 15.20 & 500 & 8.60 & 500 & 14.80 & 125 & 16.20 & 18.50 \\
\hline $\mathrm{CdLCl}_{2}$ & 125 & 16.19 & 125 & 10.60 & 125 & 17.70 & 250 & 15.90 & 22.20 \\
\hline $\mathrm{CdLI}_{2}$ & 500 & 11.50 & 250 & 9.80 & 65.50 & 23.80 & 250 & 16.00 & 17.80 \\
\hline $\mathrm{HgLI}_{2}$ & 125 & 17.66 & 125 & 10.70 & 65.50 & 23.40 & 62.50 & 21.90 & 26.50 \\
\hline
\end{tabular}




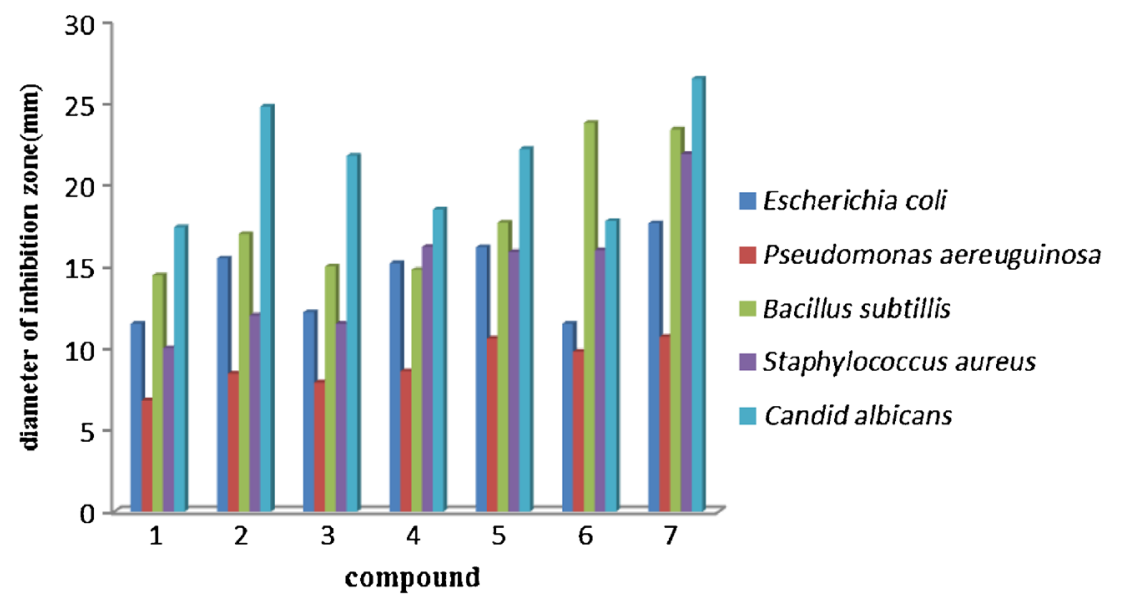

Figure 5. The inhibiton zone of the growth of bacteria and fungus (mm) (the numbers refer to entries of the tables).

metal coordination sites of the enzymes in the bacteria and/or fungi structures. In the case of antibacterial studies, it was observed that $\mathrm{HgLI}_{2}$ complex is the most active compound against Staphylococcus aureus with a MIC value of $62.5 \mu \mathrm{g} / \mathrm{mL}$. The growth of Escherichia coli and Pseudomonas aereuguinosa was more efficiently inhibited by $\mathrm{CdLCl}_{2}$ and $\mathrm{HgLI}_{2}$ complexes $(\mathrm{MIC}=125 \mu \mathrm{g} / \mathrm{mL}$ ) with respects to other compounds. Among the investigated compounds, $\mathrm{HgLI}_{2}$ and $\mathrm{CdLI}_{2}$ complexes showed higher activities against Bacillus subtillis with respect to others. The antifungal activities of the ligand and its complexes were checked by disc diffusion method and the results revealed that the inhibitory effect of the ligand was enhanced after its chelation to metal ions. In this investigation, it was recognized that $\mathrm{HgLI}_{2}$ complex efficiently prevents the growth of Candid albicans as compared with free ligand. Finally, zinc chloride, zinc bromide, cadmium chloride, zinc and cadmium iodide were found in the next positions in the antifungal activity point of view with respect to free ligand.

\section{Conclusion}

In this work, the synthesis and characterization of a new imidazolidine Schiff base ligand and some new zinc, cadmium and mercury complexes are described. The spectral data confirmed that the ligand is coordinated to metal ions in two coordination modes as bidentate and/or tridentate ligand. The electrochemical investigations showed that the ligand is reduced at four cathodic potentials and then oxidized at two anodic potentials in reverse direction. After complexation, the coordinated ligand retains its redox behaviour but with anodic and/or cathodic shifts in potential peaks. In mercury complex, two new reversible redox potentials appeared that may be assigned to redox pairs of $\mathrm{Hg}(\mathrm{II}) /(\mathrm{I})$ and
$\mathrm{Hg}(\mathrm{I}) /(0)$. TG/DTA plots of ligand and its complexes have revealed that there are no water molecules in the complex structure. Thermal analyses data of the ligand and its complex indicated that they are decomposed and lose $38.58-81.9 \%$ of total mass from the room temperature to $600^{\circ} \mathrm{C}$. Finally, the antibacterial/antifungal activities of the compounds were screened against two Gram-negative and positive bacterial strains and also a fungus. All complexes have shown more antibacterial/antifungal active compounds as compared with the free ligand.

\section{Supplementary information}

Figures S1-S12 as supplementary information can be seen at www.ias.ac.in/chemsci website.

\section{References}

1. Holm R H and Oconnor M 1971 Prog. Inorg. Chem. 14 241

2. Holm R H, Evert G W and Chakravorty A 1966 Prog. Inorg. Chem. 783

3. Coles S J, Hursthouse M B, Kelly D G, Toner A J and Walker N M 1998 J. Chem. Soc. Dalton Trans. 203489

4. Tumer M, Koksal H, Sener M K and Serin S 1999 Transition. Met. Chem. 24414

5. Budzisz E, Keppler B K, Giester G, Wozniczka M, Kufelnicki A and Nawrot B 2004 Eur. J. Inorg. Chem. 224412

6. Sedaghat T, Naseh M, Bruno G, Amiri Rudbari H and Motamedi H 2012 J. Mol. Struc. 102644

7. Jimenez M, Mateo J J and Mateo R 2000 J. Chromatogr. A 870473

8. Thati B, Noble A, Creaven B S, Walsh M, McCann M, Kavanagh K, Devereux M and Egan D A 2007 Cancer Lett. 248321

9. Mohamed R R and Fekry A M 2011 Int. J. Electrochem. Sci. 62488 
10. Ravi Krishna E, Muralidhar Reddy P, Sarangapani M, Hanmanthu G, Geeta B, Shoba Rani K and Ravinder V 2012 Spectrochim. Acta A 97189

11. Montazerozohori M, Habibi M H, Zamani-Fradonbe L and Musavi S A R 2008 Arkivoc xi 238

12. Zhan J, Zhan B, Liu J, Xu W J and Wang Z 2001 Spectrochim. Acta A $\mathbf{5 7} 149$

13. Srinivasan K and Kochi J K 1986 J. Am. Chem. Soc. 108 2309

14. Jacobsen E N, Zhang W, Muci A R, Ecker J R and Deng L 1990 J. Am. Chem. Soc. 1122801

15. Jacobsen E N 2000 Acc. Chem. Res. 33421

16. Shahabadi N, Kashanian S and Darabi F 2010 Eur. J. Med. Chem. 454239

17. Collinson S R and Fenton D E 1996 Coord. Chem. Rev. 14819

18. Santos M L P, Bagatin I A, Pereira E M and Ferreira A M C 2001 J. Chem. Soc. Dalton Trans. 6838

19. He H S, Puerta D T, Cohen S M and Rodgers K R 2005 Inorg. Chem. 447431

20. Pandeya S N, Sriram D, Ath G and DeCLecq E 1999 Eur. J. Pharm. 925

21. Wang M, Wang L F, Li Y Z, Li Q X, Xu Z D and Qu D Q 2001 Transition Met. Chem. 26307

22. Gulerman N N, Rollas S, Erdeniz H and Kiraj M 2001 J. Pharm. Sci. 261

23. Tarasconi P, Capacchi S, Pelosi G, Corina M, Albertini R, Bonati A, Dall'Aglio P P, Lunghi P and Pinelli S 2000 Bioorg. Med. Chem. 8154

24. Anitha C, Sheela C D, Tharmaraj P and Sumathi S 2012 Spectrochim. Acta A 96493

25. Habibi M H, Montazerozohori M, Lalegani A, Harington R W and Clegg W 2007 Anal. Sci. X-ray Struct. Anal Online 23 X49

26. Montazerozohori M and Musavi S A 2008 J. Coord. Chem. 613934

27. Montazerozohori M, Joohari S and Musavi S A $2009 \mathrm{~J}$. Coord. Chem. 621282

28. Montazerozohori M and Sedighipoor M 2012 Spectrochim. Acta Part A 9670
29. Montazerozohori M, Hojjati A, Joohari S and Ebrahimi H R 2012 Int. J. Electrochem. Sci. 711758

30. Montazerozohori M, Khani S, Tavakol H, Hojjat A and Kazemi M 2011 Spectrochim. Acta Part A 81122

31. Chan M E, Crouse K A, Tahir M I M, Rosli R, UmarTsafe N and Cowley A R 2008 Polyhedron 271141

32. Chakraborty J, Thakurta S, Samanta B, Ray A, Pilet G, Batten S R, Jensen P and Mitra S 2007 Polyhedron 26 5139

33. Dede B, Karipcin F and Cengiz M 2009 J. Hazard. Mater. 1631148

34. Celik C, Tumer M and Serin S 2002 Synth. React. Inorg. Met.-Org. Chem. 321839

35. El-Tabl A S, El-Saied F A, Plass W and Al-Hakimi A N 2008 Spectrochim. Acta Part A 7190

36. Yue F, Gang L, Xiu-Mei T, Ji-De W and Wei W 2008 Chin. J. Struct. Chem. 27455

37. Basak S, Sen S, Marschner C, Baumgartner J, Batten S R, Turner D R and Mitra S 2008 Polyhedron 271193

38. Chun-Hong L, Qiang W, Yan-Qing X and Chang-Wen H 2008 Chin. J. Struct. Chem. 27187

39. Gwaram N S, Ali H M, Khaledi H, Abdulla M A, Hamid A, Hadi A, Lin T K, Ching C L and Ooi C L 2012 Molecules 175952

40. Soliman A A 2001 J. Therm. Anal. Calorim. 63221

41. Sen S, Talukder P, Rosair G and Mitra S 2005 Struct. Chem. 16605

42. Zeybek B, Durmus Z, Tekiner-Gülbas B, Ak1-sener E, Yalcin I and Kilıc E 2009 Curr. Pharm. Anal. 521

43. Carbajo J, Bollo S, Nunez-Vergara L J, Campero A and Squella J A 2002 J. Electroanal. Chem. 531187

44. Salonen M, Saarinen H and Orama M 2003 J. Coord. Chem. 561041

45. Banerjee S, Wu B, Lassahn P G, Janiak C and Ghosh A 2005 Inorg. Chim. Acta 358535

46. Satoh K, Takahashi Y, Suzuki T and Sawada K 1989 J. Chem. Soc. Dalton Trans. 71259

47. Tweedy B G 1964 Phytopathalogy 55910

48. Searl J W, Smith R C and Wyard S J 1961 Proc. Phys. Soc. 781174 